\title{
Chronic or Late Lyme Neuroborreliosis: Analysis of Evidence Compared to Chronic or Late Neurosyphilis
}

\author{
Judith Miklossy*
}

International Alzheimer Research Center, Alzheimer Prevention Foundation, 1921 Martigny-Croix, Switzerland

\begin{abstract}
Whether spirochetes persist in affected host tissues and cause the late/chronic manifestations of neurosyphilis was the subject of long-lasting debate. Detection of Treponema pallidum in the brains of patients with general paresis established a direct link between persisting infection and tertiary manifestations of neurosyphilis.

Today, the same question is in the center of debate with respect to Lyme disease. The goal of this review was to compare the established pathological features of neurosyphilis with those available for Lyme neuroborreliosis. If the main tertiary forms of neurosyphilis also occur in Lyme neuroborreliosis and Borrelia burgdorferi can be detected in brain lesions would indicate that the spirochete is responsible for the neuropsychiatric manifestations of late/chronic Lyme neuroborreliosis.

The substantial amounts of data available in the literature show that the major forms of late/chronic Lyme neuroborreliosis (meningovascular and meningoencephalitis) are clinically and pathologically confirmed. Borrelia burgdorferi was detected in association with tertiary brain lesions and cultivated from the affected brain or cerebrospinal fluid. The accumulated data also indicate that Borrelia burgdorferi is able to evade from destruction by the host immune reactions, persist in host tissues and sustain chronic infection and inflammation. These observations represent evidences that Borrelia burgdorferi in an analogous way to Treponema pallidum is responsible for the chronic/late manifestations of Lyme neuroborreliosis.

Late Lyme neuroborreliosis is accepted by all existing guidelines in Europe, US and Canada. The terms chronic and late are synonymous and both define tertiary neurosyphilis or tertiary Lyme neuroborreliosis. The use of chronic and late Lyme neuroborreliosis as different entities is inaccurate and can be confusing. Further pathological investigations and the detection of spirochetes in infected tissues and body fluids are strongly needed.
\end{abstract}

Keywords: Borrelia burgdorferi, Chronic Lyme disease, Late Lyme disease, Lyme neuroborrelisosis, Chronic infection, Neurosyphilis, Syphilis, Treponema pallidum.

\section{INTRODUCTION}

Whether spirochetes persist in host tissues and play a direct role in late/chronic manifestations of tertiary syphilis was the subject of long debate. Failure to detect Treponemapallidum (T. pallidum) in infected tissues has contributed to the general concept that in the progressive degenerative process, although of syphilitic origin, spirochete infection does not play an active role. Neuropathological demonstration of T. pallidum in the brains of general paretic patientssolved the debate and defined that spirochetes play a direct role in the neuropsychiatric manifestations of late/chronic neurosyphilis. Today, the same question is in the center of debate with respect to Lyme disease. The goal of this study was to review historic data related to the debate on syphilis and compare the established pathological features of chronic or late neurosyphilis with those available on late/chronic Lyme neuroborreliosis. If the main tertiary forms occurring

*Address correspondence to this author at the International Alzheimer Research Center, Alzheimer Prevention Foundation, 1921 Martigny-Croix, CP 16, Switzerland; Tel: + 4127722 0652, + 4179207 4442;

E-mail: judithmilkossy@bluewin.ch in neurosyphilis also occur in Lyme neuroborreliosis and Borrelia burgdorferi (B. burgdorferi) can be detected in the affected brain, would indicate that in an analogous way to tertiary neurosyphilis, Borrelia spirochete can induce chronic infection and be responsible for the late neuropsychiatric manifestations of late/chronic Lyme disease.

\section{NEUROSYPHILIS}

\section{Debate on Chronic Neurosyphilis - Historic Data}

Syphilis was once a severe widespread disorder. General paresis, the most important tertiary manifestation of late/chronic neurosyphilis was recognized as a clinical entity long before the discovery of $T$. pallidum. Following Barbé [1] it has long been suspected, that syphilis, called at that time morbus venereus or verole, affects the brain and causes various neurological and psychiatric symptoms, including paralysis, tremor, hydrocephalus, mood disorder, dementia and epilepsy. As early as in 1838, Esquirol proposed that dementia paralytica is the consequence of syphilis [2]. In 1875, Fournier [3] suggested that it is syphilis, which is the cause of the neuropsychiatric manifestations of general 
paresis. It was through his reports that the importance of syphilis in several degenerative disorders has been recognized. Other authors came to the same conclusion [4, $5]$.

The etiologic agent of syphilis was discovered by Schaudinn and Hoffmann in 1905 [6]. They detected $T$. pallidum, a thin, tightly spiral organism, in syphilitic lesions. This spirochete, which is about $6-20 \mu \mathrm{m} \times 0.1-0.2 \mu \mathrm{m}$ in size, is transmitted by sexual contact. It is the frequency of positive Wassermann reaction in general paresis, which has raised the etiological importance of syphilitic infection in the late/chronic neuropsychiatric manifestations of neurosyphilis. The lack of successful detection of $T$. pallidum in infected tissues has raised the question, whether T. pallidum may contribute to the tertiary neuropsychiatric manifestations of syphilis. This resulted in a strong division of opinions in the medical and scientific communities.

Kraepelin [7] was among those who suggested that syphilitic infection is essential for the late appearance of general paresis. He claimed that general paresis is nothing more than a particular form of tertiary syphilis. In accordance, Oppenheim [8] asserted that there is a variety of meningoencephalitis, which manifests itself in the form of acute psychosis accompanied by meningeal symptoms. In opposition, others considered that general paresis is not a specific syphilitic disease of the brain and its simultaneous occurrence with syphilitic infection is a pure coincidence [9].

The infectious origin of general paresis has been recognized 100 years ago when Noguchi and Moore [10] showed the persistence of $T$. pallidum in the brains of patients suffering from general paresis. Their observation provided the proof that the disease is indeed a form of persisting syphilitic infection, specifically a chronic meningoencephalitis (meningoencephalitis paralytica) caused by the direct invasion of the brain parenchyma by $T$. pallidum. Since Noguchi and Moore, many authors detected T. pallidum in general paretic brains [11-17]. It was detected in affected tissues in late/chronic syphilis accompanied by various clinical manifestations [18]. Today it is established that $T$. pallidum is responsible for the various chronic neuropsychiatric disorders appearing months, years or decades following the primary syphilitic infection and that the spirochete is present in the lesions it causes $[18,19]$.

\section{PATHOLOGY OF NEUROSYPHILIS}

Although, it is known that once $T$. pallidum enters the body the infection is continuous, based on the main clinical and pathological manifestations they were divided into three stages (Table 1). A primary stage with the typical chancre, a generalized secondary stage as the consequence of haematogenous dissemination of spirochetes and a late, chronic or tertiary stage appearing months, years or even decades following the primary infection. "Chronic" and "late" neurosyphilis are substitutes to define tertiary neurosyphilis [20].

\section{Primary Stage}

The primary chancre develops within 2 to 6 weeks at the inoculation site, in the form of a painless ulcer from few millimeters to several centimeters in diameter. Spirochetes disseminate throughout the bloodstream within 48 hours after inoculation, before the appearance of the chancre. The chancre is shortly followed by a regional lymphadenopathy. The pathology of the chancre consists of an ulcerated lesion with mostly perivascular lymphoplasmocytic infiltrates. The inflammatory cells are predominantly lymphoplasmocytic. $T$ pallidum can be detected in the chancre. Recovery of spirochetes from the circulating blood has also been reported in primary syphilis. Healing is complete in about 6-8 weeks. It is followed by an early latent stage of several months up to 1 year.

\section{Secondary Stage: Meningeal or Early Neurosyphilis}

The typical secondary lesions appear about 6 - 7 weeks after primary infection and result from the dissemination and proliferation of $T$. pallidum throughout the body. Arthritis, cardiac and meningeal involvement, mono or polyneuritis of peripheral and/or cranial nerves, iritis together with anterior uveitis are the most characteristic features. Eruption of the skin and mucous membranes, sore throat and generalized adenopathy may also occur.

T. pallidum can reach the central nervous system (CNS) via haematogenous dissemination, via the lymphatic system or spreading along nerve fibers. Meningitis occurs in about 10 percent of the patients, but pleocytosis and increased protein level have been found in the cerebrospinal fluid

Table 1. Pathological Manifestations of Neurosyphilis

\begin{tabular}{|l|l|l|}
\hline \multicolumn{1}{|c|}{ Stages } & \multicolumn{1}{|c|}{ Types } & \multicolumn{1}{c|}{ Pathology } \\
\hline Primary Stage & Skin Manifestation (Chancre) & Local Inflammation \\
\hline $\begin{array}{l}\text { Secondary stage or } \\
\text { Early neurosyphilis }\end{array}$ & Meningeal lues & $\begin{array}{l}\text { Meningitis } \\
\text { Vasculitis } \\
\text { Neuritis } \\
\text { Mixed forms }\end{array}$ \\
\hline $\begin{array}{l}\text { Tertiary stage or } \\
\text { Late/chronic neurosyphilis }\end{array}$ & $\begin{array}{l}\text { Meningovascular syphilis } \\
\text { General paresis } \\
\text { Tabes dorsalis } \\
\text { Mixed forms }\end{array}$ & $\begin{array}{l}\text { Meningeal vasculitis with secondary cerebral } \\
\text { infarcts } \\
\text { Chronic meningoencephalitis } \\
\text { (Infiltrative and atrophic form) }\end{array}$ \\
\hline
\end{tabular}


(CSF) in about 30 percent of the patients, indicating that the inflammation of CSF is often asymptomatic. Syphilitic meningitis with seizures and focal cerebral symptoms are frequent. The meningitis is generally more accentuated on the basis of the brain and is associated with cranial nerve involvements. The characteristic histological picture is a lymphoplasmocytic meningitis and meningeal vasculitis. Syphilitic hydrocephalus is associated with a syndrome of acutely increased CSF pressure and papilledema [19]. Granular ependymitis and leptomeningeal thickening around the foramina Luschka and Magendie can block the exit of CSF to the subarachnoid space and cause occlusive hydrocephalus [21]. Cranial nerves, especially the oculomotor, abducens and acoustic nerves, may be compressed by thickened leptomeninges and undergo secondary degeneration. T. pallidum has been recovered from the CSF during secondary syphilis in 30 percent of the patients, which often correlates with other CSF abnormalities, but spirochetes may also be detected in patients with otherwise normal CSF. $T$. pallidum has been observed in the leptomeninges and in the affected leptomeningeal arteries [1, 22, 23]. As endarteritis often develops in the vasa vasorum of large and medium sized arteries, the vessel wall is susceptible to aneurysm formation [24].

The secondary manifestations of syphilis subside within 2-6 weeks. If the patients were not treated or the treatment was insufficient, following a late latent stage, lasting for months, years or even decades the clinical manifestations of late/chronic neurosyphilis (meningovascular syphilis, general paresis, tabes dorsalis) will appear. The interval from infection to the onset of symptoms is shorter for meningovascular syphilis (average 7 years) than for general paresis (15-20 years) or tabes dorsalis ( $25-30$ years).

\section{Tertiary Stage: Late or Chronic Neurosyphilis}

Tertiary syphilis may appear from a few months to several decades following the primary infection. Occlusive endarteritis and diffuse chronic inflammatory lesions without necrosis composed by lymphoplasmocytic infiltrates are the characteristic histological lesions. They are primarily found in the cardiovascular system (cardiovascular syphilis) and in the CNS [22]. Gummatous lesions with epitheloid cells mixed with lymphocytes, plasma cells and occasionally with giant cells and fibroblasts are characteristic but infrequent lesions in tertiary syphilis.

The main pathological feature of chronic or late neurosyphilis is the parenchymal brain involvement. The major forms are meningovascular syphilis with multiple cerebral infarcts, general paresis, which is the most common cause of dementia in syphilis and tabes dorsalis.

\section{a. Meningovascular Syphilis}

Meningovascular syphilis, also called cerebrovascular syphilis is characterized by chronic inflammatory and vascular lesions of the leptomeninges (see Figs $\mathbf{6}$ and $\mathbf{8}$, page 257 of Greenfield's Neuropathology [25]). All major arterial territories of the cerebral hemispheres, brain stem and cerebellum can be affected. A number of midline brainstem syndromes are also caused by meningovascular syphilis [19,
25]. The neurological symptoms start with progressive stroke and depend on the size and territory of cerebral infarcts. They may comprise hemiparesis, aphasia, but focal or generalized seizures also occur. Sixty six percent of the cases analyzed by Merritt [19] showed CSF pleocytosis. The meningeal involvement consists of chronic meningitis with varying degree of lymphoplasmocytic infiltrates accompanied by fibrous thickening of the leptomeninges. Miliary gummata with giant cells might also occur. Small ependymal granulations are frequent and few perivascular lymphoplasmocytic infiltrates in the subependymal regions also occur. Endarteritis obliterans, which was described by Heubner [26], is one of the most characteristic vascular lesion. It is characterized by lymphoplasmocytic infliltration and intimal proliferation of the arterial wall. The occlusive vascular pathology will lead to secondary thrombosis and to the obstruction of arterial wall causing multiple cerebral infarcts. In residual stages of Heubner's arteritis only the hyperplastic intima and the fibrotic degenerative changes remain.

Spirochetes were found in the leptomeninges and in the walls of affected arteries [1, 22, 23]. The diagnosis is based on the clinical symptoms, the positive serology and the detection of spirochetes in CSF or meningovascular lesions. In this meningovascular form the parenchymal involvement of the brain is secondary to the occlusive arteritis and corresponds to ischemic cerebral infarcts. The brain parenchyma itself is not infected by spirochetes.

\section{b. General Paresis}

In general paresis, the brain tissue is invaded by $T$. pallidum and the resulted chronic meningoencephalitis reflects widespread primary parenchymal damage. It generally progresses over several months, years or decades. The symptoms depend on the site, extent and severity of

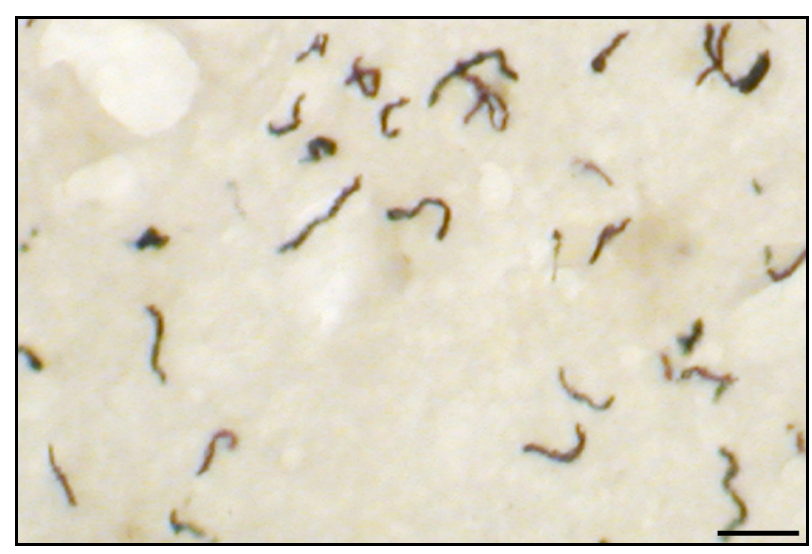

Fig. (1). The presence of high number of Treponema pallidum in late/chronic neurosyphilis. Numerous spirochetes accumulated in the cerebral cortex of a patient suffering from general paresis. Immunostaining was performed using a polyclonal anti-Treponema pallidum antibody (Biodesign, B65210R). Bar corresponds to 20 $\mu \mathrm{m}$. The illustration was done in relation with a previously published study, where the material and methods used were described in detail [34]. 
brain involvement [27]. The clinical symptoms include between many other neuropsychiatric symptoms, pupillary and reflex abnormalities, tremor and seizures. Paretic neurosyphilis was a major cause of psychosis, dementia, mood disorders and corticospinal tract diseases [19]. Behavioral changes can be present in up to $50 \%$, and simple dementia in $35 \%$ of affected individuals $[19,27]$. Infiltrative and atrophic forms of general paresis can be distinguished [14-16].

\section{Infiltrative Form of General Paresis}

In the infiltrative form strong lymphoplasmocytic infiltrates dominate (see for an illustration Fig. (1), page 871 of reference [23]). In some early cases, especially those dying in convulsive attacks, heavier cuffs of lymphocytes and plasma cells are present around smaller cortical arteries and larger cortical venules. Similar infiltrates are also frequent in the leptomeninges. The number of spirochetes in the infiltrative form is low, but with careful analysis one can find them in the affected brain.

\section{Atrophic Form of General Paresis}

The atrophic form of general paresis, called also "stationary paralysis" is clinically characterized by slowly progressive dementia, and pathologically by diffuse cortical atrophy. The cell-mediated immune response is generally poor, but even in the absence of lymphoplasmocytic infiltrates the brain parenchyma can be severely affected. The cortical atrophy is predominantly frontotemporal. Severe neuronal loss is accompanied by reactive cortical microgliosis and astrocytosis. In this atrophic form, the number of spirochetes is high [11, 14-17]. It was Noguchi and Moore [10] who first observed the presence of spirochetes in the brains of general paretic patients. They are more numerous in the frontal cortex and hippocampus [11, $14,15,28]$. Innumerable spirochetes can form black colony or plaque-like masses or perivascular accumulations and can be diffusely scattered through the cerebral cortex (Fig. 1) [11-15, 17, 29]. Pacheco e Silva [14, 15] who analyzed the brains of more than 60 general paretic patients, reported that the number of spirochetes is increasing with the severity of cortical atrophy. Neurofibrillary tangles [30, 31] and local amyloidosis [32], which revealed to correspond to betaamyloid [33] also occur in general paresis. Small multifocal myelin loss in the cerebral cortex and diffuse myelin damage in the periventricular white matter also occur. Mixed infiltrative and atrophic forms are frequent.

The diagnosis of general paresis is based on the characteristic clinical, pathological and serological findings, and on the detection of T. pallidum in the CSF or in the affected brain. It is generally accepted that the "folie de grandeur" and other neuropsychiatric aympotoms in general paresis are all attributed to the spirochetal infection of the brain [19]. The duration of this form may be from several years to several decades.

\section{c. Tabes Dorsalis}

Tabes dorsalis is another form of parenchymatous neurosyphilis. The spinal cord damage involves principally the dorsal root ganglia with secondary degeneration of posterior nerve roots and posterior columns. It manifests clinically as sensory ataxia, loss of position sensation, lancinating pains, urinary incontinence and pupillary abnormalities [19]. T. pallidum was detected in a high number in the dorsal roots of the spinal cord (for an illustration see Fig. (8), page 1060 of reference [23]).

In the pre-penicillin era, general paresis and tabes dorsalis were the most common forms of symptomatic neurosyphilis [19]. The spirochetes gained entrance to the CNS early after infection and if the treatment is not sufficient, the spirochetes develop various ways of evasion, including intracellular location and protect themselves from destruction by the host immune reactions and establish chronic infection [35, 36]. Lukehart et al., [37] isolated $T$. pallidum from the CSF after treatment of three HIV-infected subjects but not from HIV-negative cases, but T. pallidum was also isolated following "optimal" treatment of immunocompetent hosts.

It is important to notice that today's antibiotics attenuate the clinical and pathological manifestations of spirochetal diseases. They became more subtle and difficult to recognize [36]. Neurosyphilis causing psychotic illness is now rare [38] and tends to cause depression, dementia and confusional states rather than the grandiose delusions of classical general paresis of the insane. Certain forms of tertiary neurosyphilis (gummatous form, tabes dorsalis) have almost disappeared.

\section{LYME DISEASE}

\section{Debate on Chronic Lyme Neuroborrelisosis}

Lyme disease was first recognized in 1975 during an epidemic of arthritis in Lyme, Connecticut [39]. The spirochete causing Lyme disease was discovered in 1982 by Burgdorfer and was named after him B. burgdorferi [40]. It is transmitted to humans by infected ticks, which belong mostly to the genus Ixodes. Patients infected with $B$. burgdorferi may have acute signs of infection, be asymptomatic, or develop manifestations of the disease [41]. A wide range of clinical manifestations have been attributed to Lyme disease [42], including affections of skin, joints, heart, eyes [43] and symptoms of cardiovascular and CNS involvement. The term neuroborreliosis has been introduced [44] to denote the involvement of the nervous system. Neuropsychiatric manifestations occur in about $15 \%$ of the affected individuals [45-48].

The first observations indicated that the clinical and pathological manifestations of the disease are similar to those occurring in syphilis and can be divided into primary, secondary and tertiary stages. The tertiary stage includes the late or chronic neuropsychiatric manifestations [47, 49-53]. As cited from Pachner [49] "It has become clear that $B$. burgdorferi has joined Treponema pallidum, Herpes Simplex Virus, (HSV) and Human Immunodeficiency Virus (HIV) as an agent of persistent infection of the brain". Despite of these early observations, because of the difficulties to demonstrate $B$. burgdorferi in affected tissues, the link between $B$. burgdorferi infection and the late clinical manifestations of Lyme disease become the subject of strong debate [41, 5458]. While secondary neuroborreliosis is believed to be an active and ongoing infection [59], the existence of chronic 
Lyme disease induced by persistent $B$. burgdorferi infection is sharply debated.

Several mechanisms are proposed to explain the late/ chronic manifestations of Lyme disease [60]. Some authors discuss the role of immunological processes in the absence of continuing infection [59,61], the possibility of a toxic metabolic origin [62], a secondary effect of neuromodulators [59] or consider the possibility of residual symptoms [52, 63] or as a coincidental occurrence of two separate illnesses [64]. Sigal $[63,65]$ proposes seven possible pathogenic mechanisms for symptoms that may lead to the diagnosis of "chronic Lyme disease" one of which involves active and ongoing infection. Vasculitis has been postulated as the mechanism explaining nervous system injury [43, 45], based on small vessel vasculitis in peripheral neuropathy in the absence of detectable B. burgdorferi [43, 64]. Immunological processes, as a cause of vascular damage has been also suggested $[43,45,61,66]$.

As in syphilis, the lack of successful detection of spirochetes in affected tissues resulted in a strong division of opinions. There are those who reject that the chronic manifestations of the disease might be caused by active persistent infection and contest the existence of chronic Lyme disease. They claim that following a standard course of antibiotics B. burgdorferi cannot survive in affected host tissues. Persisting symptoms following such standard therapy are called "post-Lyme syndrome," which is mainly considered as psychosomatic [58].

On the other side, there are those who claim that $B$. burgdorferi can evade from destruction by the host immune reactions and cause persistent chronic infection. Accordingly, they believe that in an analogous way to T. pallidum continuing spirochetal infection may be responsible for the chronic neuropsychiatric manifestations of Lyme neuroborreliosis [41, 47, 49-51, 67, 68].

\section{Pathology of Lyme Neuroborreliosis}

The clinical and pathological manifestations of Lyme disease similarly to those of syphilis can be divided into 3 stages (Table 2).

\section{Primary Stage of Lyme Disease}

The initial expanding annular rash of erythema migrans is the site of primary infection. The inflammatory reaction consists of lymphoplasmocytic infiltrates around dermal vessels and B. burgdorferi can be detected in the lesion. As in syphilis, it is followed by an early latent stage of several weeks to months.

\section{Secondary Stage: Early Lyme Neuroborrelisosis}

The nervous system is involved in $10 \%$ to $15 \%$ of cases [69]. It is characterized by meningitis, meningeal vasculitis, meningoradiculoneuritis and cranial neuritis (GarinBujadoux-Bannwarth-Syndrome) and is frequently accompanied by CSF inflammation [70-72]. Pathological examination reveals meningitis, meningeal perivascular and vasculitic lymphoplasmocytic infiltrates [47, 50, 51, 73-75]. In this secondary stage spirochetes are present at lesion sites, but their number is low [50]. In untreated or insufficiently treated cases the neurological symptoms can progress into the late or chronic form following a late latent stage of months, years, or decades [41, 76-79]. As in syphilis, in asymptomatic patients inflamed CSF can be the only sign of ongoing infection.

\section{Tertiary Stage: Chronic/Late Lyme Neuroborreliosis}

Late/chronic Lyme neuroborreliosis is characterized by various neuropsychiatric manifestations [48, 80, 81]. The clinical symptoms include, seizures, chorea, dysphasia, ataxia, chronic spastic para- tetra- and hemiparesis $[72,76$, 82-88] sometimes recurrent [89]. As in syphilis, a broad range of neurological and psychiatric conditions are associated with Lyme disease, which include mood disorders, psychosis [90] schizophrenia [82], visual and auditory hallucinations [90, 91], paranoia, anorexia nervosa, and obsessive compulsive disorder [80-82, 92-94]. Depressive states among patients with late Lyme disease were reported to be common, ranging from $26-66 \%$ [80, 82]. Subacute and slowly progressive dementia both occurs in Lyme disease [48, 68, 81, 94-102].

As in syphilis, meningovascular form with secondary cerebral infarcts [103] and primary parenchymatous form consistent with chronic Lyme meningoencephalitis or meningoencephalomyelitis can be distinguished.

\section{a. Meningovascular Lyme Neuroborreliosis}

The clinical manifestation of meningovascular Lyme neuroborreliosis is that of a progressive stroke [47, 104-106]. The occurrence of meningeal vasculitis with multiple stenosis of large cerebral arteries with secondary cerebral infarcts in the territories of middle and posterior cerebral arteries, basilar and anterior spinal arteries have been

Table 2. Pathological Manifestations of Lyme Neuroborreliosis

\begin{tabular}{|l|l|l|}
\hline \multicolumn{1}{|c|}{ Stages } & \multicolumn{1}{c|}{ Types } & \multicolumn{1}{c|}{ Pathology } \\
\hline \hline Primary stage & Erythema migrans & Local inflammation \\
\hline $\begin{array}{l}\text { Secondary stage } \\
\text { Early Lyme neuroborreliosis }\end{array}$ & $\begin{array}{l}\text { Meningeal involvement } \\
\text { Cranial and peripheral nerves Mixed forms }\end{array}$ & $\begin{array}{l}\text { Meningitis, vasculitis } \\
\text { Neuritis }\end{array}$ \\
\hline $\begin{array}{l}\text { Tertiary stage } \\
\text { Late or chronic Lyme neuroborreliosis }\end{array}$ & $\begin{array}{l}\text { Meningovascular Lyme neuroborreliosis } \\
\text { Lyme meningoencephalitis or meningoencepha- } \\
\text { lomyelitis }\end{array}$ & $\begin{array}{l}\text { Meningitis \& occlusive vasculitis, cerebral } \\
\text { infarcts } \\
\text { Infiltrative \& atrophic forms of meningoencepha- } \\
\text { litis }\end{array}$ \\
\hline
\end{tabular}




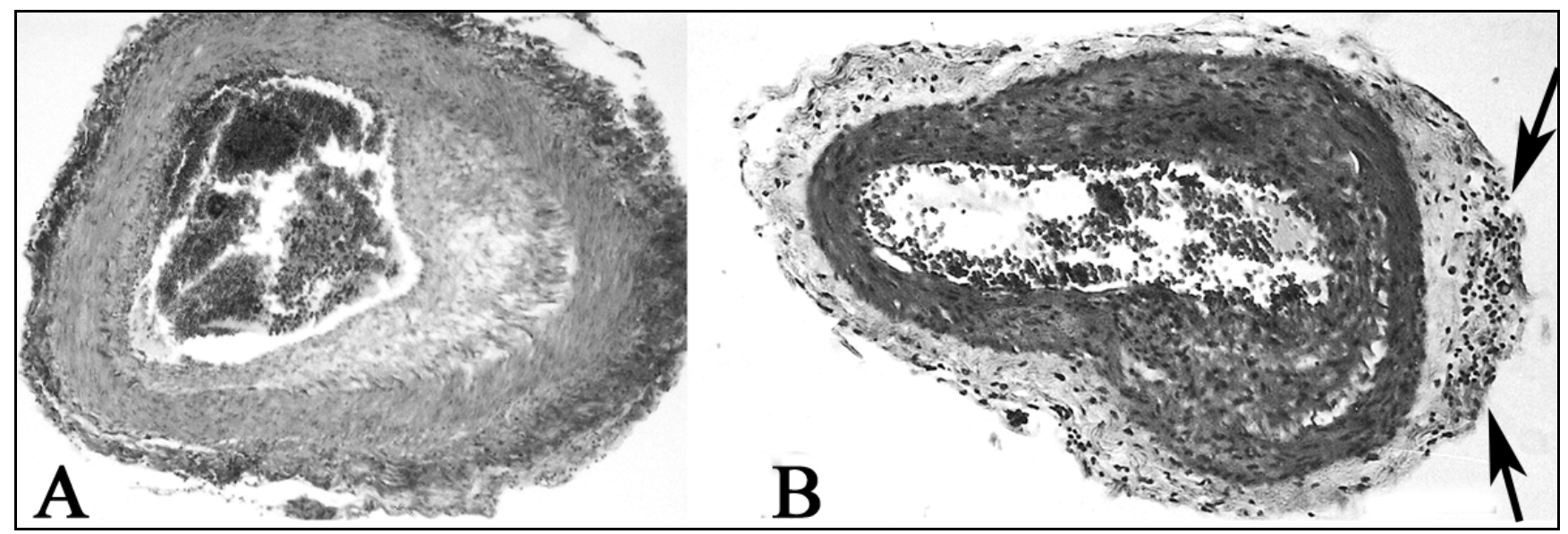

Fig. (2). Arteritis in meningovascular Lyme neuroborreliosis. The proliferation of the intima is well visible in panel A and arrows in panel B point to lymphocytic infiltrates in the thickened adventitia. Magnification: x 50. The photomicrographs were taken from a previously published study, which reported the detailed clinical and neuropathological findings of this case [47]. Compare panels A and B of this figure with those illustrated for Heubner's arteritis in neurosyphilis (Greenfield's Neuropathology, Figs 6 and 8, page 257 [25]).

repeatedly reported $[52,53,76,85,89,102,104,105,107-$ $124]$. In a pathologically confirmed case $[47,106]$ the typical meningovascular alterations of Heubner's arteritis and chronic meningitis were documented (Fig. 2). The meningitis is characterized by lymphoplasmocytic infiltrates with secondary leptomeningeal fibrosis. The occlusive vasculitis of the leptomeningeal arteries showed inflammatory infiltrates and fibrosis of the adventitia and severe intimal proliferation narrowing the vascular lumen. Some arteries showed complete obstruction of their lumen by organized thrombus. Due to their occlusion, secondary brainstem infarcts were observed in the tegmentum and in the basis of medulla oblongata. Silver impregnation methods detected helically shaped microorganisms compatible with $B$. burgdorferi in the subpial and subependymal areas. The typical clinical picture and pathological findings, the CSF pleocytosis and intrathecal production of $B$. burgdorferi specific antibodies, and the detection of spirochetes confirmed the diagnosis of meningovascular Lyme neuroborreliosis $[47,106]$. These observations show that the clinical and pathological characteristics of meningovascular Lyme neuroborreliosis are identical to those occurring in meningovascular neurosyphilis. The dominant pathology is the chronic vascular damage, which typically appears in late, chronic stage of the disease [50, 125].

\section{b. Lyme Meningoencephalitis}

Chronic Lyme meningoencephalitis

or meningoencephalomyelitis is another characteristic form of late/chronic Lyme neuroborreliosis. The clinical and pathological confirmation of meningoencephalitis with both strong and poor or absent lymphoplasmocytic infiltrates indicates that, as in general paresis, both the infiltrative and atrophic forms occur in tertiary Lyme neuroborreliosis.

\section{Infiltrative Form of Lyme Meningoencephalitis}

Ackermann et al., [87] reported 8 patients aged 18-54, with disease duration of 1 to 8 years. The typical clinical symptoms, the detection of B. burgdorferi antibodies, their intrathecal synthesis, the chronic CSF inflammation, the disruption of CSF barriers and the long lasting cerebral damage allowed the diagnosis of chronic progressive encephalomyelitis, which differs from the common and spontaneously healing meningo-polyneuritis (GarinBujadoux-Bannworth) [87]. The number of clinically confirmed cases of Lyme meningoencephalitis or myelitis is high $[81,87,96,126-143]$. The case of a child with recurrent, chronic meningoencephalitis, with progressive destruction of the brain, untreated for 15 years, represents an example of the natural course of the disease and shows the importance to consider this diagnosis in children and adults [127]. A case of fatal encephalitis with concomitant tickborne encephalitis virus and $B$. burgdorferi infection was also reported [143].

In pathologically confirmed cases of meningoencephalitis and transverse myelitis a strong cell mediated immune response dominates. Focal or more diffuse perivascular lymphocytic infiltrates, vasculitis and diffuse or nodular reactive microgliosis are the characteristic histological findings [50, 51, 61, 73, 74, 77, 144-146]. Oksi et al., [61] in their report on 3 pathologically confirmed cases concluded that cerebral lymphocytic vasculitis and multifocal encephalitis could be associated with $B$. burgdorferi infection. B. burgdorferi DNA was detected in tissue samples, and on Warthin-Starry stained sections silverimpregnated organisms compatible with $B$. burgdorferi were detected in the site of inflammatory changes [61]. In the brain of another pathologically confirmed case the leptomeninges, the subpial and subependymal areas showed severe inflammatory infiltrates. In addition to the lymphoplasmocytic infiltrates granulomatous lesions with giant cells, similar to the miliary gummatous lesions of syphilis were observed $[125,147]$. To see the similar pathology of the infiltrative form of meningoencephalitis in late or chronic neurosyphilis and Lyme neuroborreliosis, compare Fig. (1), page 871 of reference [23] with Figs $72.8,72.10,72.11$ and 72.12 , pp. 834 and 835 of reference [125].

Three cases of severe meningoencephalomyelitis were reported by Bertrand et al., [146]. B. burgdorferi was cultivated from the blood and CSF and Borrelia specific DNA was detected by PCR in the CSF in one case. In a 
patient with subacute encephalitis, brain biopsy specimen showed microgliosis without lymphoplasmocytic infiltrate and spirochetes morphologically compatible with $B$. burgdorferi were present [148]. Large areas of myelin loss in periventricular white matter areas were also described. In these pathologically confirmed cases, the role of $B$. burgdorferi infection was supported by the clinical and pathological findings, the positive serum and CSF serology, the increased number of CSF inflammatory cells and by the detection of spirochetes at lesion sites.

\section{Atrophic Form of Lyme Meningoencephalitis}

The main symptomatology of the atrophic form of Lyme meningoencephalitis, as in syphilis, is cognitive decline. The occurrence of dementia and subacute presenile dementia in Lyme disease was reported by many authors [48, 68, 81, 9497, 99-101, 149-152] and cerebral atrophy was documented by neuroradiology $[153,154]$.

In cases with slowly progressive dementia and brain atrophy, B. burgdorferi was detected or was cultivated from the brain by various investigators $[68,73,95,99,149,151$, $152,155-157]$. In three patients, with slowly progressive dementia, where $B$. burgdorferi was cultivated from the brain two had positive CSF serology. The pathological changes and the distribution of spirochetes were identical to those of $T$. pallidum in the atrophic form of general paresis $[34,68,125]$. The main pathological changes consisted of diffuse cortical atrophy with frontotemporal predominance, severe neuron loss [68] and microglial and astrocytic proliferation. The spirochetes were restricted to the cerebral cortex and were numerous (Fig. 3). The diagnosis of the atrophic form of Lyme meningoencephalitis is based on the typical clinical and pathological findings, on the positive serology, on the cultivation of $B$. burgdorferi from the cerebral cortex, and on the identification of species-specific antigens and genes in the brain [68]. Positive identification of the cultivated spirochetes as B. burgdorferi was confirmed by phylogenetic analysis of 16SrRNA [68].

One should consider, that as in syphilis rare cases with parenchymal involvement could also occur in early stages of the disease. Mixed forms of early and late/chronic manifestations or those of various late/chronic forms occur.

It is also noteworthy, that regressive evolution of cerebral infarct in meningovascular Lyme neuroborreliosis and improvement or disappearance of neuropsychiatric symptoms in Lyme encephalitis following antibiotic treatment were reported by many authors $[42,52,53,59,82,85,89$, $90,102,113-115,120,122,128,140-142,158,159]$.

\section{Pathomechanisms Involved}

Spirochetes are known to be strongly neurotropic [160]. CD14 and Toll-like receptors (TLRs) bind spirochetal surface proteins [161, 162] and through TLR signaling stimulate macrophages and microglia to secrete chemokines and cytokines and express various proinflammatory molecules in order, to remove invading spirochetes and damaged host cells. Spirochetes or their surface lipoproteins induce acute phase proteins serum amyloid A (SAA) and C Reactive Protein (CRP) and tumor necrosis factor (TNF) production [163], which play an important role in the systemic and local inflammatory changes that characterize spirochetal infections. Spirochetes are capable of activating both the classical and alternative complement pathways and employs a broad range of strategies to survive in the host. $B$. burgdorferi possesses five different surface proteins which bind immune regulators of the alternative pathway Factor $\mathrm{H}$ and FHL-1 preventing destruction by complement lysis [164, 165]. B. burgdorferi also evades complement-mediated killing by expressing a CD59-like complement inhibitory molecule with a preferential binding to C9 [166]. $B$. burgdorferi induces interleukin-12 (IL-12), a cytokine critical for driving cellular responses toward Thl subset [167169] and in this way retards antibody induction by Th2 cells. This will protect the spirochete from destruction by the adaptive immune system. Intracellular survival of $B$. burgdorferi also confers protection against host defense mechanisms. With such an evasion strategy spirochetes can subvert host immune responses. Blockade of the complement cascade enhances microbial survival and allows progressive growth of spirochetes even in an immune competent host.

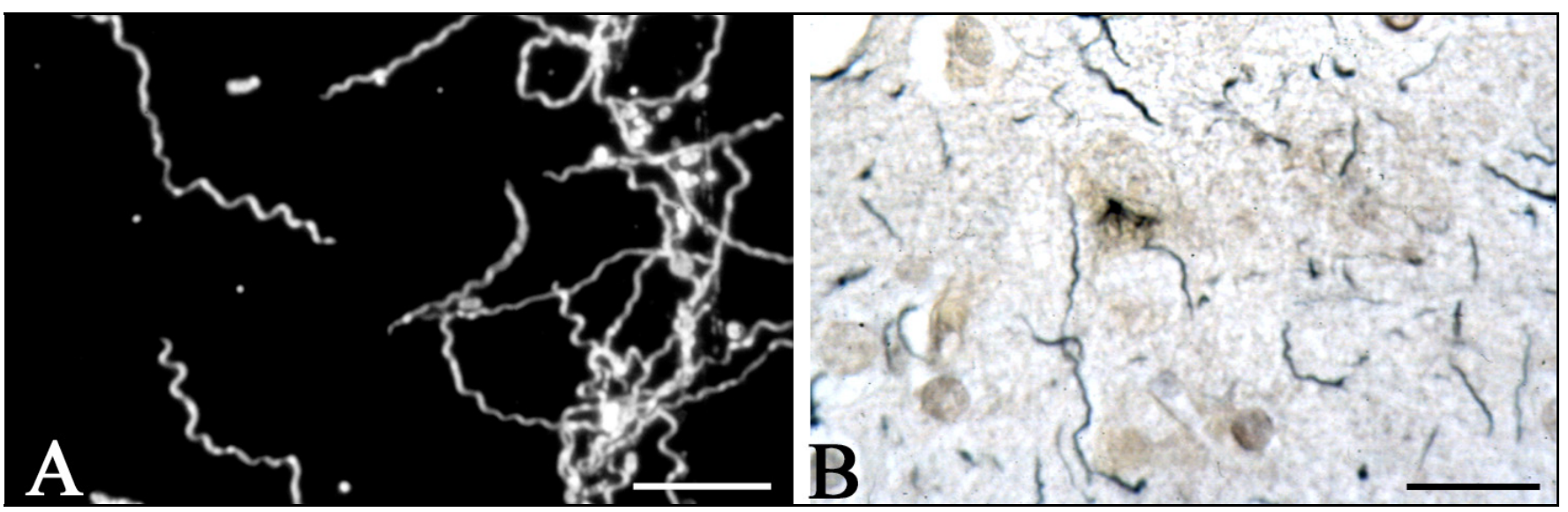

Fig. (3). B. burgdorferi cultivated and detected in the brain in the atrophic form of Lyme neuroborreliosis. Spirochetes cultivated (A) and detected by silver-impregnation technique $(\mathbf{B})$ in the brain of a patient with slowly progressive dementia who suffered from Lyme neuroborreliosis. Bars A: $20 \mu \mathrm{m}$; B: $30 \mu \mathrm{m}$. The illustrations were taken from previous studies, which were the subject of several publications $[34,68,99]$. Compare the distribution of B. burgdorferi in B with that of T. pallidum in general paresis in Fig. (1). 
B. burgdorferi, similarly to T. pallidum, is present at the sites of inflammatory lesions in many organs, including the brain $[34,47,50,61,64,68,73,95,99,125,147,149,151$, $170,171]$. Spirochetes can invade a wide range of tissues. They frequently and preferentially invade conjunctive tissue and extracellular matrix at the first stages of infection [172] and in later stages various parenchymal cells. That $B$. burgdorferi can locate intracellularly confers to the spirochete protection against host immune reactions. Infections due to intracellular pathogens are notoriously difficult to treat and cure [173].

TNF- $\alpha$ plays a critical role in host defenses against infections [64, 174]. The influence of TNF- $\alpha$ on T. pallidum and $B$. burgdorferi infections has been repeatedly reported $[163,168]$. TNF- $\alpha$ gene polymorphisms determine a strong cell mediated immune response or a weak or absent cellular response, which reflects genetic variability in cytokine production. In the tuberculoid or paucibacillary form of leprosy strong inflammatory infiltrates dominate and the number of bacteria is low. In contrast, in the lepromatous or bacillary form, the inflammatory infiltrates are poor or absent and the number of Mycobacteriuml leprae is high. Such polarity in host reactions also occurs in the infiltrative and atrophic form of general paresis in syphilis $[15,16]$. The low number of $B$. burgdorferi spirochetes in Lyme meningoencephalitis with strong lymphoplasmocytic infiltrates $[61,77]$ versus the high number of spirochetes in the atrophic form with poor or absent lymphoplasmocytic infiltrates $[68,125]$ indicate that these different host reactions also occur in chronic Lyme meningoencephalitis. The occurrence of chronic or late meningoencephalitis was also confirmed experimentally in animal models $[175,176]$ supporting the view of a direct invasion of the brain by $B$. burgdorferi in late/chronic Lyme neuroborreliosis [68, 175].

\section{CONCLUSION AND FUTURE DIRECTIONS}

Whether spirochetes persist in the affected host tissues and are responsible for the chronic/late manifestations of neurosyphilis was the subject of strong debate in the history of medicine. The evolution was slow until they concluded, based on clinical, serological and pathological observations, that the tertiary manifestations of the disease have a syphilitic infection as origin and $T$. pallidum plays a direct role in the clinical and pathological manifestations of late/chronic neurosyphilis $[1,19]$. It is the detection of $T$. pallidum in general paresis, which ended the debate. The answer came from the fields of neurology, psychiatry and neuropathology because of the distinct clinical and pathological features of secondary and tertiary neurosyphilis. Meningitis, cranial and/or peripheral neuritis are the most frequent manifestations of secondary or early neurosyphilis in contrast to the parenchymal involvement of late/chronic neurosyphilis (meningovascular syphilis, general paresis and tabes dorsalis).

The same questions are contested today with respect to Lyme disease. The existence of chronic Lyme disease is an issue of sharp debate within the medical community. The goal of the present review was to compare the established pathological findings of late/chronic neurosyphilis with those available in Lyme disease. Substantial amount of data accumulated in the literature during the past three decades showing that the clinical and pathological manifestations of late/chronic Lyme neuroborreliosis are clinically and pathologically confirmed and are similar to those of late/chronic neurosyphilis. The secondary manifestations are mostly confined to the leptomeninges, leptomeningeal arteries, cranial and peripheral nerves and the clinical signs comprise meningitis, vasculitis and neuritis. In contrast, brain parenchymal involvement defines late/chronic Lyme neuroborreliosis. B. burgdorferi was detected and cultivated from the brains of patients suffering from tertiary Lyme neuroborreliosis. The detection of B. burgdorferi and/or its specific antigens or DNA at sites of CNS lesions and the reproduction of Lyme meningoencephalitis in vivo in experimental animals are evidences for active persistent infection. These data reveal that $B$. burgdorferi, in an analogous way to $T$. pallidum, can evade from destruction by the innate and adaptive immune systems and cause chronic infection, inflammation and slowly progressive tissue damage. Continuous infection by $B$. burgdorferi can cause the manifestations of late/chronic Lyme neuroborreliosis, including stroke, cognitive decline and various other neuropsychiatric conditions. As B. burgdorferi can persist in the host tissues, even in the absence of lymphoplasmocytic infiltrates, an attempt to detect the spirochete in body fluids and tissues is important when the clinical and/or the histopathologic features suggest Lyme disease. Future investigations in this direction are crucial.

The patient should be thoroughly evaluated for the confirmation or exclusion of Lyme disease. In optimal conditions the confirmation of late/chronic Lyme neuroborreliosis should be based on the characteristic clinical symptoms on the serological and pathological findings, on the cultivation or detection of spirochetes or their specific antigens or DNA in the affected tissues or body fluids. In cases with suspicion of Lyme neuroborreliosis, following exclusion of the involvement of the nervous system, exclusion of other peripheral infection is also important. Co-infections can aggravate the clinical and pathological manifestations of the disease and should be considered. Other chronic infections and medical conditions that could explain the symptoms should be carefully considered as well.

It is known that antibiotic therapy is less efficient in chronic neurosyphilis and Lyme neuroborreliosis, however, syphilis was almost eradicated by the use of Penicillin and improvement in neuropsychiatric symptoms or complete recovery of patients suffering from late/chronic neurosyphilis and Lyme neuroborreliosisis was frequently reported. These observations are also indicative of ongoing infection and point to the necessity of careful consideration of $B$. burgdorferi in the etiology of stroke, dementia, mood disorders and the various other neuropsychiatric symptoms associated with Lyme disease. They also underline the necessity of treatment.

Special attention should be paid to the clinical, serological, and CSF findings compatible with $B$. burgdorferi infection, as successful treatment of early Lyme disease [53] can prevent the expensive and devastating consequences of late/chronic Lyme disease. B. burgdorferi in 
a similar way to $T$. pallidum, invades various cells including neurons and glial cells. As the spirochete can locate intracellularly and survive in more resistant pleomorphic forms [34], for an efficient eradication of the infection, combined antibiotic treatment for a longer period of time should be considered, in a similar way that it is established for the treatment of tuberculosis and leprosy. Because of the potential side effects of antibiotics further studies for highly efficient alternative treatments, are critical.

As cortisone was a common way to reactivate syphilitic infection in experimental animals [19] the use of corticosteroids or other immunosuppressive therapy alone is not recommended. Presently, antibiotic treatment is the therapy of choice to kill spirochetes.

Importantly, the existence of late Lyme disease is approved by all official guidelines in the U.S., Canada and Europe. The terms "late" and "chronic" Lyme disease, as in syphilis, are synonymous and define tertiary Lyme disease $[20,125]$. The use of "chronic" Lyme disease as a different entity is inaccurate and confusing.

Further research, exchange of knowledge and open discussions in the medical and scientific communities at an international level are essential to solve faster all the questions, which still remain to be answered with respect to Lyme disease.

\section{CONFLICT OF INTEREST}

The author declares that she has no potential conflict of interest.

\section{ACKNOWLEDGEMENTS}

I would like to thank all my colleagues and friends in Europe, the U.S, Canada and Australia for their encouragement, and constant help and support. I am grateful to Pushpa Darekar and Rudolf Kraftsik for their loyal support, which helped this research in so many different ways. The work was supported by the Prevention Alzheimer International Foundation, Switzerland.

\section{APPENDIX}

Fig. (1). The presence of high number of Treponema pallidum in late/chronic Lyme neuroborreliosis. Numerous spirochetes accumulated in the cerebral cortex of a patient suffering from general paresis. Immunostaining was performed using a polyclonal anti-Treponema pallidum antibody (Biodesign, B65210R). Bar corresponds to $20 \mu \mathrm{m}$. The illustration was done in relation with a previously published study, where the material and methods used were described in detail [34].

Fig. (2.) Arteritis in meningovascular Lyme neuroborreliosis. The proliferation of the intima is well visible in panel A and arrows in panel B point to lymphocytic infiltrates in the thickened adventitia. Magnification: x 50. The photomicrographs were taken from a previously published study, which reported the detailed clinical and neuropathological findings of this case [47].

Fig. (3). Borrelia burgdorferi cultivated and detected in the brain in the atrophic form of Lyme neuroborreliosis.
Spirochetes cultivated (A) and detected by silverimpregnation technique (B) in the brain of a patient with slowly progressive dementia who suffered from Lyme neuroborreliosis. Bars: $\mathrm{A}=20 \mu \mathrm{m}, \mathrm{B}=30 \mu \mathrm{m}$. The illustrations were taken from previous studies, which were the subject of several publications [34, 68, 99].

\section{REFERENCES}

[1] Barbé A. Précis de Psychiatrie: Paris; Masson 1950: pp. 385-493.

[2] Esquirol JE. Des maladies mentales. Paris: Baillières 1838.

[3] Fournier A. La Syphilis du Cerveau. Leçons cliniques. Paris: Masson G 1879.

[4] Rumpf T. Die syphilitischen Erkrankungen des Nervensystems. 1887: 620 .

[5] Dawson WR. The spinal changes in general paralysis. Br J Psych 1901; 47: 598-9.

[6] Schaudinn FR, Hoffmann E. Vorläufiger Bericht über das Vorkommen von Spirochaeten in syphilitischen Krankheitsprodukten und bei Papillomen (527-534, 2 Abb.). In: Arbeiten aus dem Kaiserlichen Gesundheitsamt 1905: pp. 527-34.

[7] Kraepelin EW. Psychiatrie. Ein Lehrbuch für Studierende und Ärzte. Klinische Psychiatrie. Barth Verlag: Leipzig 1904.

[8] Oppenheim H. Beiträge zur Diagnostik une Therapie der Gesch wülste im Bereich des zentralen Nervensystems 1907.

[9] Nonne M. Syphilis und Nervensystem. Berlin: Verlag von S Karger, 1902.

[10] Noguchi H, Moore J W. A demonstration of Treponema pallidum in the brain of general paralysis cases. J Exp Med 1913; 17: 232-8.

[11] Jahnel F. Die Spirochaeten im Zentralnervensystem bei der Paralyse. Zeitschr ges Neurol Psychiatrie 1921; 73: 310-31.

[12] Hauptmann A. Spirochaten und Hirnrindengefaesse bei Paralyse. Z Neur 1920; 57: 122-37.

[13] Schob F. Ueber miliare Nekrosen und abscesse in der Hirnrinde eines Paralytikers und ihre Beziehungen zur Spirocheata pallida. Ztschr ges Neurol Psychiat 1925; 95: 588-612.

[14] Pacheco e Silva AC. Localisation du Tréponéma Pallidum dans le cerveau des paralytiques généraux. Considérations thérapeutiques Rev Neurol 1926; 2: 558-65.

[15] Pacheco e Silva AC. Espirochetose dos centros nervos Memorias do hospicio de Juquery 1926-27; 3-4: 1-27.

[16] Rizzo C. Ricerche sulle spirochete nel cervello dei paralitici. Riv Pathol Nerv 1931; 37: 797-814.

[17] Dieterle RR. Spirochetosis of the central nervous system in general pralysis. Am J Psychiatry 1928; 7: 37-67.

[18] Strong JP. Pathology. In: Rypins medical lincensure examination. NY: Lippincott William and Wilkins 1981: pp. 449-85.

[19] Merritt HH, Adams RD, Solomon HC. Neurosyphilis. London: Oxford University Press 1946

[20] Mandell GL, Bennett JE., Dolin R. Neurosyphilis. Principles and Practice of Infectious Diseases $5^{\text {th }}$ ed: US: Elsevier 2002; pp. 247689.

[21] Greenfield JG, Stern RO. Syphilitic hydrocephalus in the adult. Brain 1932; 55: 367-90.

[22] Kornyei I. Neuropathologia. Akadémiai Kiado, Budapest 1987: pp. 417.

[23] Lubarsch O, Henke F, Roessle R. Erkrankungen des Zentralen Nervensystems II. Berlin: Springer 1958.

[24] Jackman JD, Jr., Radolf JD. Cardiovascular syphilis. Am J Med 1989; 87: 425-33.

[25] Greenfield JG. Greenfiled's neuropathology. Blackwood W and Corsellis JAN Eds, $3^{\text {rd }}$ ed, Edinburgh: Edward Arnold Ltd, 1977.

[26] Heubner O. Die Luetische Ekrankung der Hirnarterien. Germany: Vogel, Leipzig 1874.

[27] Gilad R, Lampl Y, Blumstein G, Dan M. Neurosyphilis: the reemergence of an historical disease. Isr Med Assoc J 2007; 9: 117 8 .

[28] Steiner G. Morphologic appearances of spirochetal reproduction in tissues. Arch Pathol 1940; 29: 189-99.

[29] Herschmann H. Ueber eine direkt nekrotisierende Form der Hirnsyphilis. Ztschr ges Neurol Psychiat 1920; 55: 27-39.

[30] Bonfiglio F. Di speciali reperti in un caso di probabile sifilide cerebrale. Riv Sperim Fren 1908; 4: 196-206. 
[31] Perusini G. Ueber klinisch und histologisch eigenartige psychische Erkrankungen des spaeteren Lebensalters. Histologische und hispopathologische Arbeiten, Nissl, F, Alzheimer A Eds, Gustave Fischer, Jena 1910; vol 3: pp. 297-351.

[32] Volland W. Die Kolloide Degeneration des Gehirns bei progressiver Paralyse in ihrer Beziehung zur lokalen Amyloidose. Dtsch Path Gesellsch 1938; 31: 515-20.

[33] Miklossy J, Rosemberg S, McGeer PL. Beta amyloid deposition in the atrophic form of general paresis. In: Alzheimer's Disease: New

advances Eds: Iqbal K, Winblad B, J Avila Medimond Intyernational Proceedings Proceedings of the 10th International Congress on Alzheimer's Disease (ICAD) 2006: pp. 429-33.

[34] Miklossy J, Kasas S, Zurn AD, McCall S, Yu S, McGeer PL. Persisting atypical and cystic forms of Borrelia burgdorferi and local inflammation in Lyme neuroborreliosis. J Neuroinflammation 2008; 5: 40.

[35] Hook EW 3rd. Diagnosing neurosyphilis. Clinical infectious diseases : an official publication of the Infectious Diseases Society of America 1994; 18: 295-7.

[36] Hook EW, 3rd, Marra CM. Acquired syphilis in adults. N Engl J Med 1992; 326: 1060-9.

[37] Lukehart SA, Hook EW 3rd, Baker-Zander SA, Collier AC, Critchlow $\mathrm{CW}$, Handsfield $\mathrm{HH}$. Invasion of the central nervous system by Treponema pallidum: implications for diagnosis and treatment. Ann Intern Med 1988; 109: 855-62.

[38] Dewhurst K. The neurosyphilitic psychoses today. A survey of 91 cases. Br J Psychiatry 1969; 115: 31-8.

[39] Steere AC, Malawista SE, Snydman DR et al. Lyme arthritis: an epidemic of oligoarticular arthritis in children and adults in three connecticut communities. Arthritis Rheum 1977; 20: 7-17.

[40] Burgdorfer W, Barbour AG, Hayes SF, Benach JL, Grunwaldt E, Davis JP. Lyme disease-a tick-borne spirochetosis? Science 1982; 216: 1317-9.

[41] Donta ST. Treatment of patients with persistent symptoms and a history of Lyme disease. N Engl J Med 2001; 345: 1424-5.

[42] Stanek G, O'Connell S, Cimmino M, et al. European Union Concerted Action on Risk Assessment in Lyme Borreliosis: clinical case definitions for Lyme borreliosis. Wien Klin Wochenschr 1996; 108: 741-7.

[43] Meier C, Grehl H. Vasculitic neuropathy in the Garin-BujadouxBannwarth syndrome. A contribution to the understanding of the pathology and pathogenesis of the neurological complications in Lyme borreliosis. Dtsch Med Wochenschr 1988; 113: 135-8.

[44] Veenendaal-Hilbers JA, Perquin WV, Hoogland PH, Doornbos L. Basal meningovasculitis and occlusion of the basilar artery in two cases of Borrelia burgdorferi infection. Neurology 1988; 38: 13179.

[45] Garcia-Monco JC, Benach JL. Lyme neuroborreliosis. Ann Neurol 1995; 37: 691-702.

[46] Steere AC. Lyme disease. N Engl J Med 1989; 321: 586-96.

[47] Miklossy J, Kuntzer T, Bogousslavsky J, Regli F, Janzer RC. Meningovascular form of neuroborreliosis: similarities between neuropathological findings in a case of Lyme disease and those occurring in tertiary neurosyphilis. Acta Neuropathol 1990; 80: 568-72.

[48] Fallon BA, Nields JA. Lyme disease: a neuropsychiatric illness. The Am J Psychiatr 1994; 151: 1571-83.

[49] Pachner AR. Lyme disease. Trends Neurosci 1989; 12: 177-81.

[50] Duray PH. Histopathology of clinical phases of human Lyme disease. Rheum Dis Clin North Am 1989; 15: 691-710.

[51] Duray PH, Steere AC. Clinical pathologic correlations of Lyme disease by stage. Ann N Y Acad Sci 1988; 539: 65-79.

[52] Kruger H, Heim E, Schuknecht B, Scholz S. Acute and chronic neuroborreliosis with and without CNS involvement: a clinical, MRI, and HLA study of 27 cases. J neurol 1991; 238: 271-80.

[53] Wilke M, Eiffert H, Christen HJ, Hanefeld F. Primarily chronic and cerebrovascular course of Lyme neuroborreliosis: case reports and literature review. Arch Dis Childhood 2000; 83: 67-71.

[54] Aberer E. Neuroborreliosis or borrelia hysteria. This case becomes a nightmare!. MMW Fortschr Med 2006; 148: 8 .

[55] Stricker RB, Lautin A. The Lyme Wars: time to listen. Expert Opin Investig Drugs 2003; 12: 1609-14

[56] Stricker RB, Johnson L. Chronic Lyme disease and the 'Axis of Evil'. Future Microbiol 2008; 3: 621-4.

[57] Aletras V. The perfect size of the NHS hospitals in Greece.
[58] Feder HM Jr, Johnson BJ, O'Connell S, et al. A critical appraisal of "chronic Lyme disease". N Engl J Med 2007; 357: 1422-30.

[59] Schmutzhard E, Pfausler B, Gasse T, Hittmair-Delazer M, Benke $\mathrm{T}$. Follow-up and sequelae in chronic neuroborreliosis. Wien Med Wochenschr 1995; 145: 183-6.

[60] Wilske B, Busch U, Fingerle V, et al. Immunological and molecular variability of OspA and OspC. Implications for Borrelia vaccine development. Infection 1996; 24: 208-12.

[61] Oksi J, Kalimo H, Marttila RJ, et al. Inflammatory brain changes in Lyme borreliosis. A report on three patients and review of literature. Brain 1996; 119 ( Pt 6): 2143-54.

[62] Halperin JJ, Volkman DJ, Wu P. Central nervous system abnormalities in Lyme neuroborreliosis. Neurology 1991; 41: 1571-82.

[63] Kontodimopoulos N, Nanos P, Niakas D. Balancing efficiency of health services and equity of access in remote areas in Greece. Health Policy 2006; 76:49-57.

[64] Sigal LH. Lyme disease: a review of aspects of its immunology and immunopathogenesis. Annu Rev Immunol 1997; 15: 63-92.

[65] Sigal LH. Persisting complaints attributed to chronic Lyme disease: possible mechanisms and implications for management. Am J Med 1994; 96: 365-74.

[66] Garcia-Monco JC. Pathomechanisms of neuroborreliosis. Wien Med Wochenschr 1995; 145: 174-7.

[67] Miklossy J. Chronic inflammation and amyloidogenesis in Alzheimer's disease -- role of Spirochetes. J Alzheimers Dis 2008; 13: 381-91.

[68] Miklossy J, Khalili K, Gern L, et al. Borrelia burgdorferi persists in the brain in chronic lyme neuroborreliosis and may be associated with Alzheimer disease. J Alzheimers Dis 2004; 6: 639-49; discussion 73-81.

[69] Halperin JJ. Neurologic manifestations of lyme disease. Curr Infect Dis Rep 2011; 13: 360-6.

[70] Pachner AR, Steere AC, Sigal LH, Johnson CJ. Antigen-specific proliferation of CSF lymphocytes in Lyme disease. Neurology 1985; 35: 1642-4.

[71] Stiernstedt G. Tick-borne Borrelia infection in Sweden. Scand J Infect Dis 1985; 45 (Suppl) : 1-70.

[72] Hansen K, Lebech AM. The clinical and epidemiological profile of Lyme neuroborreliosis in Denmark 1985-1990. A prospective study of 187 patients with Borrelia burgdorferi specific intrathecal antibody production. Brain 1992; 115 (Pt 2): 399-423.

[73] Duray PH. The surgical pathology of human Lyme disease. An enlarging picture. Am J Surg Pathol 1987; 11 (Suppl 1): 47-60.

[74] Duray PH, Steere AC. The spectrum of organ and systems pathology in human Lyme disease. Zentralbl Bakteriol Mikrobiol Hyg A 1986; 263: 169-78.

[75] Meurers B, Kohlhepp W, Gold R, Rohrbach E, Mertens HG. Histopathological findings in the central and peripheral nervous systems in neuroborreliosis. A report of three cases. J Neurol 1990; 237: 113-6.

[76] Hammers-Berggren S, Grondahl A, Karlsson M, von Arbin M, Carlsson A, Stiernstedt G. Screening for neuroborreliosis in patients with stroke. Stroke 1993; 24: 1393-6.

[77] Shadick NA, Phillips CB, Logigian EL, et al. The long-term clinical outcomes of Lyme disease. A population-based retrospective cohort study. Ann Intern Med 1994; 121: 560-7.

[78] Asch ES, Bujak DI, Weiss M, Peterson MG, Weinstein A. Lyme disease: an infectious and postinfectious syndrome. J Rheumatol 1994; 21: 454-61.

[79] Donta ST. Tetracycline therapy for chronic Lyme disease. Clin Infect Dis: 1997; 25; (Suppl 1): S52-6.

[80] Fallon BA, Nields JA, Parsons B, Liebowitz MR, Klein DF. Psychiatric manifestations of Lyme borreliosis. J Clin Psychiatry 1993; 54: 263-8.

[81] Pennekamp A, Jaques M. Chronic neuroborreliosis with gait ataxia and cognitive disorders. Praxis (Bern 1994) 1997; 86: 867-9.

[82] Roelcke U, Barnett W, Wilder-Smith E, Sigmund D, Hacke W. Untreated neuroborreliosis: Bannwarth's syndrome evolving into acute schizophrenia-like psychosis. A case report. J Neurol 1992; 239: $129-31$.

[83] Renard C, Marignier S, Gillet Y, et al. Acute hemiparesis revealing a neuroborreliosis in a child. Arch de Pediatrie 2008; 15: 41-4.

[84] Seijo Martinez M, Grandes Ibanez J, Sanchez Herrero J, GarciaMonco JC. Spontaneous brain hemorrhage associated with Lyme neuroborreliosis. Neurologia 2001; 16: 43-5. 
[85] Deloizy M, Devos P, Stekelorom T, Testard D, Belhadia A. Left sided sudden hemiparesis linked to a central form of Lyme disease. Rev Neurol (Paris) 2000; 156: 1154-6.

[86] Stiernstedt G, Gustafsson R, Karlsson M, Svenungsson B, Skoldenberg B. Clinical manifestations and diagnosis of neuroborreliosis. Ann N Y Acad Sci 1988; 539: 46-55.

[87] Ackermann R, Gollmer E, Rehse-Kupper B. Progressive Borrelia encephalomyelitis. Chronic manifestation of erythema chronicum migrans disease of the nervous system. Dtsch Med Wochenschr 1985; 110: 1039-42.

[88] Halperin JJ. Nervous system manifestations of Lyme disease. Rheum Dis Clin North Am 1989; 15: 635-47.

[89] Brower MC, Rollins N, Roach ES. Basal ganglia and thalamic infarction in children. Cause and clinical features. Arch Neurol 1996; 53: 1252-6.

[90] van den Bergen HA, Smith JP, van der Zwan A. Lyme psychosis. Ned Tijdschr Geneeskd 1993; 137: 2098-100.

[91] Stricker RB, Winger EE. Musical hallucinations in patients with Lyme disease. South Med J 2003; 96: 711-5.

[92] Hassett AL, Radvanski DC, Buyske S, et al. Role of psychiatric comorbidity in chronic Lyme disease. Arthritis Rheum 2008; 59: 1742-9.

[93] Cameron D. Severity of Lyme disease with persistent symptoms. Insights from a double-blind placebo-controlled clinical trial. Minerva medica 2008; 99: 489-96.

[94] Almeida OP, Lautenschlager NT. Dementia associated with infectious diseases. Int Psychogeriatr / IPA 2005; 17 (Suppl 1): S65-77.

[95] MacDonald AB. Borrelia in the brains of patients dying with dementia. JAMA 1986; 256: 2195-6.

[96] Reik L Jr, Burgdorfer W, Donaldson JO. Neurologic abnormalities in Lyme disease without erythema chronicum migrans. Am J Med 1986; 81: 73-8

[97] Dupuis MJ. Multiple neurologic manifestations of Borrelia burgdorferi infection. Rev Neurol 1988; 144: 765-75.

[98] Smith JL. Neuro-ocular Lyme borreliosis. Neurol Clin 1991; 9: 3553.

[99] Miklossy J. Alzheimer's disease--a spirochetosis? Neuroreport 1993; 4: 841-8

[100] Schaeffer S, Le Doze F, De la Sayette V, Bertran F, Viader F. Dementia in Lyme disease. Presse Med 1994; 23: 861.

[101] Waniek C, Prohovnik I, Kaufman MA, Dwork AJ. Rapidly progressive frontal-type dementia associated with Lyme disease. J Neuropsychiatry Clin Neurosci 1995; 7: 345-7.

[102] Lebas A, Toulgoat F, Saliou G, Husson B, Tardieu M. Stroke Due to Lyme Neuroborreliosis: Changes in Vessel Wall Contrast Enhancement. J Neuroimag 2012; 22(12): 210-2.

[103] Blanc F. Neurologic and psychiatric manifestations of Lyme disease. Med Mal Infect 2007; 37: 435-45

[104] Uldry PA, Regli F, Bogousslavsky J. Cerebral angiopathy and recurrent strokes following Borrelia burgdorferi infection. J Neurol Neurosurg Psychiat 1987; 50: 1703-4.

[105] Olsson JE, Zbornikova V. Neuroborreliosis simulating a progressive stroke. Acta Neurol Scand 1990; 81: 471-4.

[106] Kuntzer T, Bogousslavsky J, Miklossy J, Steck AJ, Janzer R, Regli F. Borrelia rhombencephalomyelopathy. Arch Neurol 1991; 48: 832-6.

[107] Hanny PE, Hauselmann HJ. Lyme disease from the neurologist's viewpoint. Schweiz Med Wochenschr 1987; 117: 901-15.

[108] Brogan GX, Homan CS, Viccellio P. The enlarging clinical spectrum of Lyme disease: Lyme cerebral vasculitis, a new disease entity. Ann Emerg Med 1990; 19: 572-6.

[109] Reik L Jr. Stroke due to Lyme disease. Neurology 1993; 43: 27057 .

[110] Defer G, Levy R, Brugieres P, Postic D, Degos JD. Lyme disease presenting as a stroke in the vertebrobasilar territory: MRI. Neuroradiology 1993; 35: 529-31

[111] Keil R, Baron R, Kaiser R, Deuschl G. Vasculitis course of neuroborreliosis with thalamic infarct. Nervenarzt 1997; 68: 33941.

[112] Schmitt AB, Kuker W, Nacimiento W. Neuroborreliosis with extensive cerebral vasculitis and multiple cerebral infarcts. Nervenarzt 1999; 70: 167-71.

[113] Klingebiel R, Benndorf G, Schmitt M, von Moers A, Lehmann R. Large cerebral vessel occlusive disease in Lyme neuroborreliosis. Neuropediatrics 2002; 33: 37-40.
[114] Laroche C, Lienhardt A, Boulesteix J. Ischemic stroke caused by neuroborreliosis. Archives de pediatrie: organe officiel de la Societe francaise de pediatrie 1999; 6: 1302-5.

[115] Zhang Y, Lafontant G, Bonner FJ, Jr. Lyme neuroborreliosis mimics stroke: a case report. Arch phys Med Rehab 2000; 81: 519 21.

[116] May EF, Jabbari B. Stroke in neuroborreliosis. Stroke 1990; 21: 1232-5.

[117] Heinrich A, Khaw AV, Ahrens N, Kirsch M, Dressel A. Cerebral vasculitis as the only manifestation of Borrelia burgdorferi infection in a 17-year-old patient with basal ganglia infarction. Eur Neurol 2003; 50: 109-12.

[118] Romi F, Krakenes J, Aarli JA, Tysnes OB. Neuroborreliosis with vasculitis causing stroke-like manifestations. Eur Neurol 2004; 51: 49-50.

[119] Van Snick S, Duprez TP, Kabamba B, Van De Wyngaert FA, Sindic CJ. Acute ischaemic pontine stroke revealing lyme neuroborreliosis in a young adult. Acta Neurol Belg 2008; 108: 103-6.

[120] Sparsa L, Blanc F, Lauer V, Cretin B, Marescaux C, Wolff V. Recurrent ischemic strokes revealing Lyme meningovascularitis. Rev Neurol (Paris) 2009; 165: 273-7.

[121] Topakian R, Stieglbauer K, Aichner FT. Unexplained cerebral vasculitis and stroke: keep Lyme neuroborreliosis in mind. Lancet Neurol 2007; 6: 756-7.

122] Rey V, Du Pasquier R, Muehl A, Peter O, Michel P. Multiple ischemic strokes due to Borrelia garinii meningovasculitis. Rev Neurol (Paris) 2010; 166: 931-4.

[123] Midgard R, Hofstad H. Unusual manifestations of nervous system Borrelia burgdorferi infection. Arch Neurol 1987; 44: 781-3

[124] Schmiedel J, Gahn G, von Kummer R, Reichmann H. Cerebral vasculitis with multiple infarcts caused by lyme disease. Cerebrovasc Dis 2004; 17: 79-81.

[125] Miklossy J. Biology and neuropathology of dementia in syphilis and Lyme disease. Handb Clin Neurol 2008; 89: 825-44.

[126] Diringer MN, Halperin JJ, Dattwyler RJ. Lyme meningoencephalitis: report of a severe, penicillin-resistant case. Arthritis Rheum 1987; 30: 705-8.

[127] Bensch J, Olcen P, Hagberg L. Destructive chronic borrelia meningoencephalitis in a child untreated for 15 years. Scand J Infect Dis 1987; 19: 697-700.

[128] Weder B, Wiedersheim P, Matter L, Steck A, Otto F. Chronic progressive neurological involvement in Borrelia burgdorferi infection. J Neurol 1987; 234: 40-3.

[129] Bogsrud TV, Odegaard B. Tick-borne borreliosis. A case of chronic meningoencephalitis caused by Borrelia burgdorferi. Tidsskr Nor Laegeforen 1987; 107: 25-7.

[130] Fenelon G, Chaine P, Leche J, Guillard A. Isolated meningoencephalitis in Lyme disease. Ann Med Interne (Paris) 1987; 138: 14950 .

[131] Ferroir JP, Reignier A, Nicolle MH, Guillard A. Meningoradiculoencephalitis in Lyme disease. A case with major regressive mental disorders. Presse Med 1988; 17: 697.

[132] Ponz E, Graus F, Alvarez R, Sarmiento X, Vidal J, Grau JM. Meningoencephalomyelitis caused by Borrelia burgdorferi: a case without epidemiologic history or chronic migratory erythema. Med Clin 1989; 93: 218-20.

[133] Neumarker KJ, Dudeck U, Plaza P. Borrelia encephalitis and catatonia in adolescence. Nervenarzt 1989; 60: 115-9.

[134] Omasits M, Seiser A, Brainin M. Recurrent and relapsing course of borreliosis of the nervous system. Wien Klin Wochenschr 1990; 102: 4-12.

[135] Czyrny M, Jura E, Seniow J, Baranska M, Wilske B, Czlonkowska A. [Severe meningoencephalitis in Borrelia burgdorferi infection]. Neurol Neurochir Pol 1998; 32: 387-93.

[136] Oschmann P, Dorndorf W, Hornig C, Schafer C, Wellensiek HJ, Pflughaupt KW. Stages and syndromes of neuroborreliosis. J Neurol 1998; 245: 262-72.

[137] Cassarino DS, Quezado MM, Ghatak NR, Duray PH. Lymeassociated parkinsonism: a neuropathologic case study and review of the literature. Arch Pathol Lab Med 2003; 127: 1204-6.

[138] Drouet A, Meyer X, Guilloton L, et al. Acute severe leukoencephalitis with posterior lesions due to Borrelia burgdorferi infection. Presse Med 2003; 32: 1607-9. 
[139] Pfefferkorn T, Feddersen B, Schulte-Altedorneburg G, Linn J, Pfister HW. Tick-borne encephalitis with polyradiculitis documented by MRI. Neurology 2007; 68: 1232-3.

[140] Kacinski M, Zajac A, Skowronek-Bala B, Kroczka S, Gergont A, Kubik A. CNS Lyme disease manifestation in children. Przeglad lekarski 2007; 64 (Suppl 3): 38-40.

[141] De Cauwer H, Declerck S, De Smet J, et al. Motor neuron disease features in a patient with neuroborreliosis and a cervical anterior horn lesion. Acta clinica Belgica 2009; 64: 225-7.

[142] Kawano Y, Shigeto H, Shiraishi Y, Ohyagi Y, Kira J. Case of Borrelia brainstem encephalitis presenting with severe dysphagia. Clin Neurol 2010; 50: 265-7.

[143] Oksi J, Viljanen MK, Kalimo H, et al. Fatal encephalitis caused by concomitant infection with tick-borne encephalitis virus and Borrelia burgdorferi. Clinical infectious diseases: an official publication of the Infectious Dis Soc Am 1993; 16: 392-6.

[144] Iero I, Elia M, Cosentino FI, et al. Isolated monolateral neurosensory hearing loss as a rare sign of neuroborreliosis. Neurol Sci $2004 ; 25: 30-3$

[145] Nadelman RB, Nowakowski J, Forseter G, et al. The clinical spectrum of early Lyme borreliosis in patients with cultureconfirmed erythema migrans. Am J Med 1996; 100: 502-8.

[146] Bertrand E, Szpak GM, Pilkowska E, et al. Central nervous system infection caused by Borrelia burgdorferi. Clinico-pathological correlation of three post-mortem cases. Folia neuropathologica 1999; 37: 43-51.

[147] Liegner KB, Duray P, Agricola M, et al. Lyme disease and the clinical spectrum of antibiotic responsive chronic meningoencephalomyelitides. J Spirochetal Tick-borne Dis 1997; 4: 61-73.

[148] Pachner AR, Duray P, Steere AC. Central nervous system manifestations of Lyme disease. Arch Neurol 1989; 46: 790-5.

[149] MacDonald AB, Miranda JM. Concurrent neocortical borreliosis and Alzheimer's disease. Hum Pathol 1987; 18: 759-61.

[150] Juchnowicz D, Rudnik I, Czernikiewicz A, Zajkowska J, Pancewicz SA. Mental disorders in the course of lyme borreliosis and tick borne encephalitis. Przegl Epidemiol 2002; 56 (Suppl 1): 3750 .

[151] Miklossy J. Alzheimer's disease - a neurospirochetosis. Analysis of the evidence following Koch's and Hill's criteria. J Neuroinflammation 2011; 8: 90 .

[152] Miklossy J, Kasas S, Janzer RC, Ardizzoni F, Van der Loos H. Further ultrastructural evidence that spirochaetes may play a role in the aetiology of Alzheimer's disease. Neuroreport 1994; 5: 1201-4.

[153] Aasly J, Nilsen G. Cerebral atrophy in Lyme disease. Neuroradiology 1990; 32: 252.

[154] Tarasow E, Ustymowicz A, Zajkowska J, Hermanowska-Szpakowicz T. [Neuroborreliosis: CT and MRI findings in 14 cases. Preliminary communication]. Neurol Neurochir Pol 2001; 35: 803-13.

[155] MacDonald AB. Transfection "Junk" DNA - a link to the pathogenesis of Alzheimer's disease? Med Hypotheses 2006; 66: 1140-1.

[156] MacDonald AB. Plaques of Alzheimer's disease originate from cysts of Borrelia burgdorferi, the Lyme disease spirochete. Med Hypotheses 2006; 67: 592-600.

[157] Meer-Scherrer L, Chang Loa C, Adelson ME, et al. Lyme disease associated with Alzheimer's disease. Curr Microbiol 2006; 52: 3302.

[158] Christen HJ, Hanefeld F. Lyme borreliosis in childhood. Monatsschr Kinderheilkd 1993; 141: 513-26.

[159] Topakian R, Stieglbauer K, Nussbaumer K, Aichner FT. Cerebral vasculitis and stroke in Lyme neuroborreliosis. Two case reports and review of current knowledge. Cerebrovasc Dis 2008; 26: 45561.

[160] Gastinel P. Précis de bactériologie médicale. Collections de récis médicaux. 1949: pp. 781-837.

[161] Bulut Y, Faure E, Thomas L, Equils O, Arditi M. Cooperation of Toll-like receptor 2 and 6 for cellular activation by soluble tuberculosis factor and Borrelia burgdorferi outer surface protein A lipoprotein: role of Toll-interacting protein and IL-1 receptor signaling molecules in Toll-like receptor 2 signaling. J Immunol 2001; 167: 987-94.

[162] Sellati TJ, Bouis DA, Kitchens RL, et al. Treponema pallidum and Borrelia burgdorferi lipoproteins and synthetic lipopeptides activate monocytic cells via a CD14-dependent pathway distinct from that used by lipopolysaccharide. J Immunol 1998; 160: 5455-64.

163] Marangoni A, Aldini R, Sambri V, Giacani L, Di Leo K, Cevenini R. Production of tumor necrosis factor alpha by Treponema pallidum, Borrelia burgdorferi s.1., and Leptospira interrogans in isolated rat Kupffer cells. FEMS Immunol Med Microbiol 2004; 40: 187-91.

[164] Kraiczy P, Skerka C, Kirschfink M, Zipfel PF, Brade V. Mechanism of complement resistance of pathogenic Borrelia burgdorferi isolates. Int Immunopharmacol 2001; 1: 393-401.

[165] Kraiczy P, Wurzner R. Complement escape of human pathogenic bacteria by acquisition of complement regulators. Mol Immunol 2006; 43: 31-44.

[166] Pausa M, Pellis V, Cinco M, et al. Serum-resistant strains of Borrelia burgdorferi evade complement-mediated killing by expressing a CD59-like complement inhibitory molecule. J Immunol 2003; 170: 3214-22.

[167] Radolf JD, Goldberg MS, Bourell K, Baker SI, Jones JD, Norgard MV. Characterization of outer membranes isolated from Borrelia burgdorferi, the Lyme disease spirochete. Infect Immun 1995; 63: 2154-63

[168] Rasley A, Anguita J, Marriott I. Borrelia burgdorferi induces inflammatory mediator production by murine microglia. $\mathrm{J}$ Neuroimmunol 2002; 130: 22-31

[169] Ramesh G, Alvarez AL, Roberts ED, et al. Pathogenesis of Lyme neuroborreliosis: Borrelia burgdorferi lipoproteins induce both proliferation and apoptosis in rhesus monkey astrocytes. Eur $\mathbf{J}$ Immunol 2003; 33: 2539-50.

[170] Aberer E, Kersten A, Klade H, Poitschek C, Jurecka W. Heterogeneity of Borrelia burgdorferi in the skin. Am J Dermatopathol 1996; 18: 571-9.

[171] Riviere GR, Riviere KH, Smith KS. Molecular and immunological evidence of oral Treponema in the human brain and their association with Alzheimer's disease. Oral Microbiol Immunol 2002; 17: 113-8

[172] Duray PH, Yin SR, Ito Y, et al. Invasion of human tissue ex vivo by Borrelia burgdorferi. The J infect dis 2005; 191: 1747-54.

[173] Mahmoud AA. The challenge of intracellular pathogens. N Engl J Med 1992; 326: 761-2.

[174] Shaw MA, Donaldson IJ, Collins A, et al. Association and linkage of leprosy phenotypes with HLA class II and tumour necrosis factor genes. Genes Immun 2001; 2: 196-204.

[175] Pachner AR, Delaney E, O'Neill T, Major E. Inoculation of nonhuman primates with the N40 strain of Borrelia burgdorferi leads to a model of Lyme neuroborreliosis faithful to the human disease. Neurology 1995; 45: 165-72.

[176] Chang YF, Novosel V, Chang CF, et al. Experimental induction of chronic borreliosis in adult dogs exposed to Borrelia burgdorferiinfected ticks and treated with dexamethasone. Am J Vet Res 2001; 62: $1104-12$

\section{(C) Judith Miklossy; Licensee Bentham Open.}

This is an open access article licensed under the terms of the Creative Commons Attribution Non-Commercial License (http://creativecommons.org/licenses/by-nc/3.0/) which permits unrestricted, non-commercial use, distribution and reproduction in any medium, provided the work is properly cited. 